Chemotherapy 1996;42(suppl 2):I-III

\title{
Contents, Supplement 2, 1996
}

\section{Kayser, F.H. Chairman's Introduction 1}

Kayser, F.H. Basic Aspects of Antibiotic Resistance in the Multiresistant Staphylococcus: An Overview 2

Voss, A.; Kresken, M. Antibiotic Resistance in Staphylococci in Europe 13

Berger-Bachi, B. Update on Methicillin Resistance Mechanisms in Staphylococci 19

Noble, W.C.

Carbon, C.

Resistance to Glycopeptide Antibiotics in 27

Staphylococcus aureus: An Emerging Problem?

Impact of Multiresistance on Antimicrobial Therapy of 30 Staphylococcal Infections

Hedin, G.

Epidemiology of Coagulase-Negative Staphylococci in Hospital

38

Proctor, R.A.; Vesga, O.; Otten, M.F.; Koo, S.-P.; Yeaman, M.R.; Sahl, H.-G.: Bayer, A.S. Staphylococcus aureus Small Colony Variants Cause Persistent and Resistant Infections 47

Trilla, A.; Marco, F.; Moreno, A.V.; Prat, A.; Vila, J.; Bayas, J.M.; Jimenez de Anta, M.T. Prevention and Control of Methicillin-Resistant Staphylococcus aureus Nosocomial Infection in Barcelona (Spain)

53

Subject Index

60

KARGER

E-Mail karger@karger.ch Fax+416130612 34

(C) 1996 S.Karger AG, Basel

III 